\title{
Performance of Yam Marketing in Yewa Division of Ogun State, Nigeria
}

\author{
Akerele*, Ezekiel Olaoluwa , Yusuf and Misturh Olaide \\ Department of Agricultural Economics, Farm Management, Nigeria
}

*Corresponding author: Akerele, Department of Agricultural Economics, Farm Management, Nigeria

\begin{abstract}
Globally, quest for empowerment have increased the need of investigation into the economic activities of marketers. This study focused performance of yam marketing in Yewa Division of Ogun State, Nigeria with the specific objectives of describing the socio economic characteristics of the yam marketers; describe the cost and return structure of yam marketing; estimate the marketing margin and efficiency of yam and identify the problems militating against yam marketing in the study area. A two-stage sampling technique was used to select ten (10) markets. From each market, twelve (12) yam marketers were randomly selected and interviewed making a total of one hundred and twenty (120) sampled marketers for the study. Data collected were analyzed using descriptive statistics and budgetary analysis. Results obtained revealed that majority (95.8\%) of the marketers were female with an average age of 41 years per marketer, married (85.8\%), and illiterate with more than half of the respondents. Gross Margin (GM) and Net Income (NI) per month were N75,808.30 and N66,491.63 respectively implying that yam marketing was profitable in the study area. The Benefit Cost Ratio (BCR), Profitability Index (PI), Return on investment (ROI), Operating Ratio (OPR) and Rate of Return on Variable Cost (RRVC) were computed as 1.66, 0.40, 0.66, 0.55, and 1.83 respectively. These measures also show that yam marketing is profitable in the study area. An assessment of the marketing margin and marketing efficiency revealed the margin of N554.10. The marketing efficiency (ME) was estimated at 1.51. The problems militating against yam marketing were numerous but the main constraint facing them includes bad roads, poor storage, credit sales and poor and instable price of yam. Based on the study findings, it is recommended that Government should provide an enabling environment through the provision of needed infrastructural facilities especially good roads and yam marketing should also form an association to regulate market price and prevent the effect of glut in supply.
\end{abstract}

Keywords: Yam; Marketing Margin; Marketing Efficiency; Profitability; Budgetary Analysis

\section{Introduction}

Nigeria's socio-economic history and development has been very closely tied to its agricultural sector Egbuna, [1]. Agriculture holds the key to rural development, poverty alleviation and overall economic development Oluwafemi [2]. The sector accounted for about $31-42 \%$ of Gross Domestic Product (GDP) between the year 2005 and 2008. In addition, it provides paid and selfemployment for over $70 \%$ of the nation's population (Nigerian Export Promotion Council NEPC [3]. The Food Crop Sub-sector (with maize, sorghum, millet, rice, yam, cocoyam and cassava as the main food crops grown in the country) contributed about $28 \%$ to GDP representing about $75-76 \%$ of the share of the agricultural sector's contribution to GDP CBN [4]. Agriculture belongs to the real sector of Nigerian economy and it is characterized by multitude of small-scale farmers scattered over wide expanse of land area, with small holdings ranging from 0.05 - 3.0 hectares per farm land, rudimentary farm systems, low capitalization and low yield per hectare Okoedo-Okojie and Okwuokenye [5]. Root and tuber crops comprise crop covering several genera. They are staple food crops, being the source of daily carbohydrate intake for the large populace of the world. The term root and tuber crop refers to any growing plant that store edible materials in the subterranean root, corm or tuber Toluwase and Sekumade [6]. Yam is a member of this important class of food. Yams (Dioscorea spp) are annual or perennial tuber-bearing and climbing plants with over 60 species out of which six are economically important in terms of food and medicine.

Yambelongsto the genus "Dioscorea" and family "Dioscoreaceae". It is an important tuber crop of the tropics. Yam is a tropical crop 
with many species, which originated from South East Asia and was brought to West Africa in the 16th century Toluwase and Sekumade [6]. Yam is an important food crop especially in the yam zone of West Africa, comprising Cameroon, Nigeria, Benin, Togo, Ghana and Cote de 'vore. This zone produces more than $90 \%$ of the total world production, estimated at $20-25$ million tons per year Adeniji et al. [7]. Nigeria is noted to be a leading World producer of yam FAO [8]. The report noted that out of the World production of over 30 million tonnes per annum, Nigeria produces about 25 million tones. It is one of the principal tuber crops in the Nigeria economy, in terms of land under cultivation and in the volume and value of production Bamire and Amujoyegbe [9]. Agronomically, yam can be grown from whole tuber, seed yam or micro-sett IITA [10]. The report (IITA 2005) showed that use of micro-sett (small pieces of yam cut from "mother seed yams") under plastic mulch could increase the multiplication rate tenfold over conventional system. Okwuokenye and Onemolease [11] noted that on the part of profitability that yam production is very profitable and that more marketers can still enter the market and still make profit. A wholesaler is an intermediary entity (person or enterprise) in the distribution channel whose role is to buy in bulk and sell to resellers (also known as retailers) rather than to consumers. Wholesalers obtain large quantities of products from producers, may store them, and may break them down into cases or sets and other smaller units more convenient for retailers to buy; this process is best described as "breaking bulk".

Marketing is defined as a process of satisfying human needs by bringing products to people in the proper form and at a proper time and place. Marketing has economic value because it gives form, time, place, utility to products and services. The marketing of agricultural products begins at the farm when the farmer harvests his products. The product when it is harvested cannot usually go directly to the consumers. Firstly, it is likely to be located some distance from the place of consumption in regular and continuous manner throughout the year. Secondly, storage is required to adjust supply to meet demand. Thirdly, a product when it has been harvested is rarely in a form acceptable to consumers. Therefore, it must be sorted, cleared and processed in various ways and must be presented to the consumer in convenient quality and quantities for sale. Finally the farmer expects payment when his produce leaves his possession, and hence some financial arrangements must be made to cover all the various stages until the retailer sells the products to the final consumer. Marketing covers all business functions including production and in its broadest sense, it also covers production decision. So it can be argued that in farming such decision as the variety of crops to grow or the breed of animal to keep are marketing decisions. The primary role of an integrated marketing system is to add form, place, time and possession utility, so that the subjective satisfaction of consumers is maximized.

Marketing generally entails the movement of goods (agricultural products) from on producer to the final consumer, a route that is often linked with middlemen of which the retailer is one Okoedo-Okojie and Okwuokenye [12]. Wholesale marketing involves buying in large quantities from the farmers and selling in small quantity to the retailers and final consumers Kotler [13].
He asserted that the retailer's sales volume comes primarily from wholesalers. To improve on the wholesale marketing of yam would demand an understanding of the marketing function and cost. Okoedo-Okojie and Okwuokenye [12] asserted that whatever affects marketing functions and cost will ultimately affect the agricultural development process and socioeconomic wellbeing of the citizenry. This is because too high a cost will limit customer's ability to buy and this will eventually limit agricultural production (yam inclusive). Despite the benefits derived from yam production, it is realized that it has earned little attention from scientific research compared to other food crops. This situation has not only affected the production but also the marketing of yam Okwuokenye and Onemolease [14]. This study therefore seeks to bridge the gap so that a drastic increase in production and wholesale marketing of the product can be achieved.

Markets are prerequisites for enhancing agro-based economic growth and increasing rural incomes in the medium term particularly for the rural poor households. Subsistence food crop production cannot improve rural incomes without marketoriented production systems. These require the intensification of agricultural production systems, increased commercialization and specialization in higher-value crops. And these must be built upon the establishment of efficient and well-functioning markets and trade systems-ones that keep transaction costs low, minimize risk, extend information to all players and that do not either exclude or work contrary to the interests of the poor-especially those living in areas of marginal productivity and weak infrastructure. Food marketing is a very important but rather neglected aspect of agricultural development. In developing countries, more emphasis is usually placed on policies to increase food production with little or no consideration on how to distribute the food produced efficiently and in a manner that will enhance increased productivity. Food marketing is a very important but rather neglected aspect of agricultural development. In developing countries, more emphasis is usually placed on policies to increase food production with little or no consideration on how to distribute the food produced efficiently and in a manner that will enhance increased productivity Robert et al. [15].

\section{Objectives of the study}

The broad objective is to study the performance of yam marketing in Yewa Division of Ogun State, Nigeria. The specific objectives are to examine the cost and return structure of yam marketing and estimate the marketing margin and efficiency of yam in the study area.

\section{Research Methodology}

\section{Study Area}

The Yewa Division of Ogun State was used as study area. The marginalization of Yewa in Ogun State is crystal clear from its inability to occupy the State Government House the moment the State was created in 1976 and beyond. While other regions within the State have been to the apex position and even recycling it. Traditionally speaking, Ogun State is divided into four; Egba, Ijebu, 
Remo and Yewa respectively. But into three for administrative purposes as enshrined in the country Constitution, these divisions are Ogun Central Senatorial District mainly made up of Egba with six LGAs, Ogun East Senatorial District with Ijebu and Remo with nine LGAs and Ogun West Senatorial District comprises of Yewa with five LGAs Lamidi and Ogunkunle [16]. Yewa formerly Egbado is made up of seven different tribes which was the main reason the cover name of the region was changed in 1995 to Yewa. Even at that, Awori one of the tribe in the region failed to agree with the problem created by the $20^{\text {th }}$ century scholars by classifying her as Yewa, rather see herself as a unique entity within the region with link to the Egbas. It was all these factors that would later affect the socio-economic and political development of the region despite its closeness to the international borderline Olusegun [17] (Figure 1).

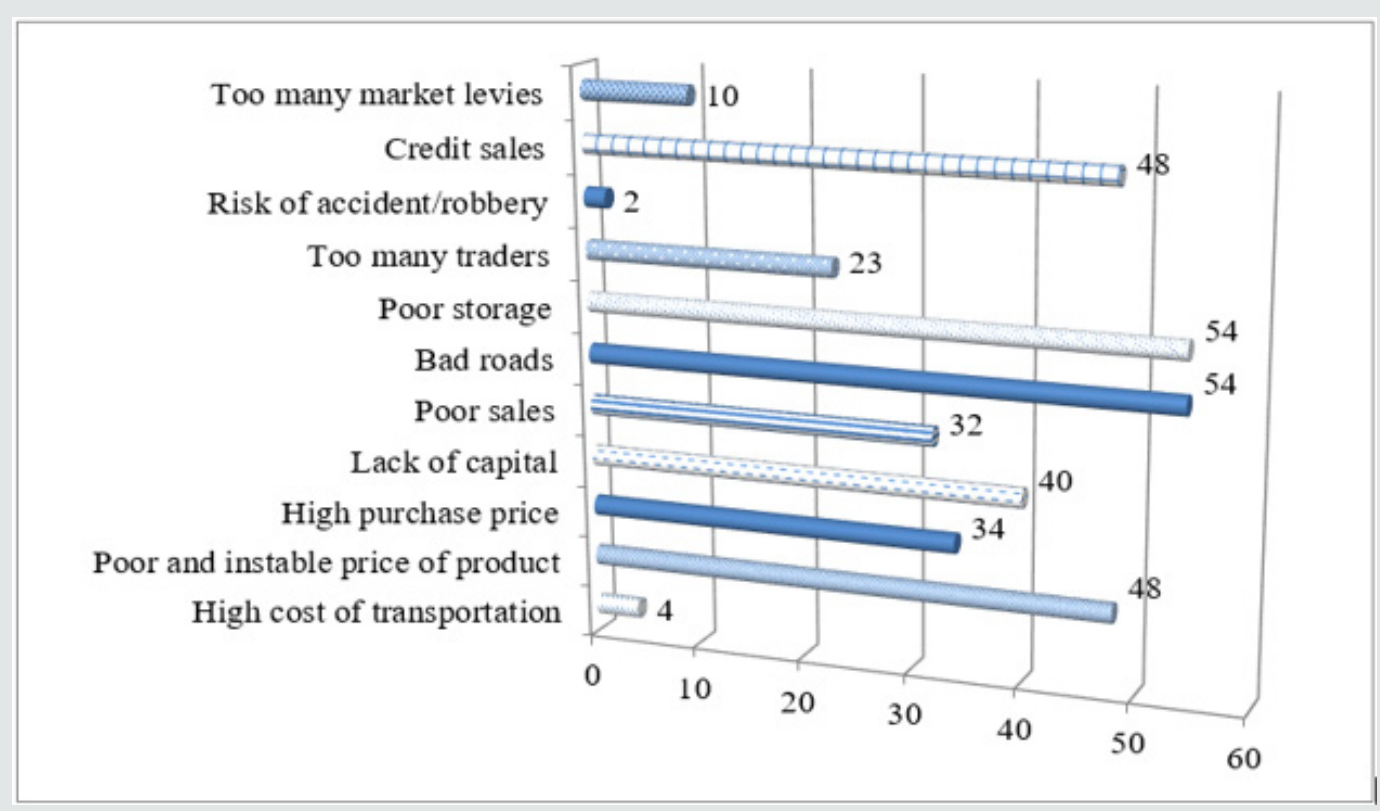

Figure 1: Distribution of respondents' problem militating against yam marketing in the area. Source: Data Analysis, 2018

\section{Sources and Methods of Data Collection}

Both primary and secondary data were used for the study. The primary data were collected through the use of well-structured (pre-tested) questionnaire, while the secondary data were obtained from published journals, books, internet, periodicals, government official websites and other relevant sources.

\section{Sampling Techniques}

A two-stage sampling technique was employed in this study to select a cross section of 120 yam marketers in the areas. Two (2) Local Government Areas were randomly selected out of five (5) Local Government Areas that make up Yewa Division of Ogun State. Five (5) markets were purposively selected from each of the LGAs making a total of ten (10) markets. Twelve (12) yam marketers were selected in each market making a total of one hundred and twenty (120) marketers in the study area.

\section{Methods of Data Analysis}

The data obtained from this study were analyzed using both descriptive and inferential analytical techniques. Descriptive statistical tools (such as frequency distribution tables and percentages, charts, measures of central tendency and proportions) were used to describe the socio-economic characteriswtics of the respondents. While, inferential statistics (such as Budgetary
Analysis and Marketing Efficiency models) were used to examine cost-return structure of the respondents and marketing efficiency of the yam marketers. frequency distribution tables and percentages, charts, measures of central tendency and proportions.

\section{Cost and Return Structure Analysis of Yam Marketing}

Budgetary analysis was used to estimate the cost and return structure of yam marketing in the study area. The Net Income (NI) was obtained thus:

$\mathrm{NI}=\mathrm{TR}-\mathrm{TC}$

$\mathrm{TMC}=\mathrm{TFC}+\mathrm{TVC}$

Where:

$\mathrm{TR}=$ Total Revenue from the enterprise (

TVC = Total Variable Cost from enterprise ( $\mathrm{N})$

$\mathrm{TFC}=$ Total Fixed Cost of enterprise (

TMC $=$ Total Marketing Cost of enterprise $(\mathrm{N})$

$\mathrm{NI}=$ Net Income $(\mathrm{N})$

The result of the budgetary analysis was used to obtain the following ratios. 
Benefit-Cost Ratio (BCR): TR/TMC.

Profitability Index or Return on Sale = NI/TR

Rate of Returns on Investment (\%) RRI = (NI/TMC)*100

$\mathrm{OR}=$ Operating Expense Ratio $=\mathrm{TVC} / \mathrm{TR}$

RRVC $=$ Rate of Return on Variable Cost $=($ TR/TVC $) * 100$

\section{Market Margin and Marketing Efficiency of Yam}

With respect to the marketing and profit margins of among the various components on the distribution chain of yam, the Deconstructed Marketing Margin was used. The Deconstructed Marketing Margin allows for the estimation of marketing margins and profit margins. The marketing margin is computed as the difference between the cost of purchasing yam and the total revenue derived from the sale of yam. Following Tuffour and Dokurugu [18], the formulae are specified as follows:

Where:

$$
\boldsymbol{M}=\frac{\sum_{1}^{n}[\boldsymbol{R}-\mathbb{C}]}{N}
$$

$\mathrm{TR}=$ Total Revenue

$\mathrm{TC}=$ Total Cost

$\mathrm{n}=$ Sample Size

Marketing Efficiency (ME) as Abdou (2004) indicated is given in the form:

$$
\text { EI }=100-\left[\frac{M}{\not L} \times 100\right]
$$

Where:

$$
\begin{aligned}
& \mathrm{MC}=\text { Total Marketing Cost; } \\
& \text { MM = Total Marketing Margin }
\end{aligned}
$$

According to Abdou (2004), the marketing efficiency estimates marketing margins as representing the difference between purchasing and selling prices of marketers compared to the real marketing costs. A positive sign estimates would justify application

\begin{tabular}{|c|c|c|}
\hline Variable & Frequency & Percentage \\
\hline \multicolumn{3}{|c|}{ Age (years) } \\
\hline$\leq 30$ years & 10 & 8.3 \\
\hline 31 - 40 years & 40 & 33.3 \\
\hline $41-50$ years & 43 & 35.8 \\
\hline 51 - 60 years & 19 & 15.8 \\
\hline$>60$ years & 8 & 6.7 \\
\hline \multicolumn{3}{|c|}{ Sex } \\
\hline Male & 5 & 4.2 \\
\hline Female & 115 & 95.8 \\
\hline \multicolumn{3}{|c|}{ Marital Status } \\
\hline Single & 4 & 3.3 \\
\hline
\end{tabular}
of such services, making it efficient, and a negative estimate would

\begin{tabular}{|c|c|c|}
\hline Married & 103 & 85.8 \\
\hline Widow & 11 & 9.2 \\
\hline Divorced & 2 & 1.7 \\
\hline \multicolumn{3}{|c|}{ Educational Level } \\
\hline Primary Education & 41 & 34.2 \\
\hline Secondary Education & 16 & 13.3 \\
\hline Tertiary Education & 1 & 0.8 \\
\hline No Formal Education & 62 & 51.7 \\
\hline \multicolumn{3}{|l|}{ Religion } \\
\hline Islam & 64 & 53.3 \\
\hline Christianity & 54 & 45 \\
\hline Others & 2 & 1.7 \\
\hline \multicolumn{3}{|c|}{ Marketing Experience } \\
\hline $1-10$ years & 64 & 53.3 \\
\hline 11 - 20 years & 35 & 29.2 \\
\hline 21 - 30 years & 18 & 15 \\
\hline$>30$ years & 3 & 2.5 \\
\hline \multicolumn{3}{|l|}{ Household Size } \\
\hline$\leq 4$ persons & 26 & 21.7 \\
\hline 5 - 8 persons & 92 & 76.6 \\
\hline$\geq 9$ persons & 2 & 1.7 \\
\hline \multicolumn{3}{|c|}{ Membership of Marketing Association } \\
\hline \multicolumn{3}{|l|}{ Yes } \\
\hline \multirow[t]{2}{*}{ No } & 109 & 90.8 \\
\hline & 11 & 9.2 \\
\hline TOTAL & 120 & 100 \\
\hline
\end{tabular}
indicate otherwise (Table 1).

Table 1: Socio-Economic Characteristics of the Respondents.

\section{Results and Discussion}

Results of socio-economic characteristics of the yam marketers in the study area are presented below. The ability of the marketers to take advantage of emerging opportunities that could improve marketing efficiency and profitability could be influenced by their age. The age distribution of respondents as presented in Table 1 indicates that $69.1 \%$ of the yam marketers are between ages 31 and 50 , while $6.7 \%$ of them are above 60 years, meaning that most yam marketers in the study area are in their middle age. The average age was estimated at 41 years. An economic active age that can make positive contribution to agricultural production which may translate to improved profitability of yam marketing. It is necessary to describe the sex of the respondents for possible inference and generalization on how it relates to yam marketing. The finding revealed that majority (65.8\%) of the respondents was females. This showed that yam marketing seems solely a female business in the area, which confirms Oladapo et al. [19] and Okoedo-Okojie and Okwuokenye [12], but shows difference with Okwuokenye and Onemolease [11] that reported mixed distribution in equal proportions in their various studies. The relative sole distribution may be as a result of social barriers. Marital status is expected to influence respondents' level of responsibilities which could have positive or negative influence on their disposition to economic activities including the yam marketing. It was revealed in Table 1 that $85.8 \%$ of the yam marketers are married, $3.3 \%$ were observed 
as single, while $9.2 \%$ of are widows. The result shows that most of the yam marketers in the study area are married and therefore yam marketing would serve as a means to meet the needs of the family.

Education is of great importance in decision making. It can indirectly influence the respondents' understanding of marketing dynamics and ways to maximize gains. Finding revealed that $51.7 \%$ of the yam marketers had non-formal education; $34.2 \%$ had primary education, $13.3 \%$ had secondary education, while $0.8 \%$ had secondary education. This result reveals that majority of yam marketers in the study area do not have formal education. Notably, formal education is an essential tool for the adoption of effective communication system that encourages increase in the marketing of any agricultural produce. Thus, with low level of literacy in the study area, yam marketers would hardly adopt new marketing strategy which could improve their levels of profits ceteris paribus. Analysis of the religion of the respondents revealed that majority $(53.3 \%)$ of the yam marketers practiced Islam as religion while $45 \%$ of them were Christian and only $1.7 \%$ did not practice Christianity and Muslim. Substantial percentages of the two dominant religions are well represented in the study area. Experience is an important determinant of efficiency and perhaps profitability. The study further revealed that majority (53.3\%) of the yam marketers have been in the business for about 10years while $29.2 \%$ of the yam marketers have been in the business within 11 to 20 years, $15 \%$ of the yam marketers have been in the business within 21 to $30 y e a r s$ and the remaining $2.5 \%$ of the yam marketers have been in the business above 30years. The average experience of wholesalers was determined at 14 years and 6 months. This shows that the managerial ability of the marketers can be inferred to be reasonably good.

Household size may determine the family Labour at the disposal of a yam marketer. In terms of the household size distribution of the yam marketers, the results indicate that $21.7 \%$ of the yam marketers had household size of between 1 and 4 inhabitants, with $76.6 \%$ belonging to the household size of between 5 and 8 persons. The relative size of the household implies availability of Labour which could be an opportunity for the yam business. Data showed the percentage distribution of respondents by membership of marketing association. The result showed that majority of the respondents (90.8\%) subscribed to the membership of marketing association, whereas $9.2 \%$ did not subscribe to the membership of marketing association. Those involved in Marketing Association did so because of easy access to extension services, market and credit facilities.

\section{Cost and Return Structure Analysis of Yam Market- ing}

Budgetary Analysis was used to determine the cost and returns of yam marketing in the study area. The analysis indicating Total Revenue (TR), Total Variable Cost (TVC), Total Fixed Cost (TFC), Total Marketing Cost (TMC), Gross Margin (GM), Net Income (NI), Benefit-Cost Ratio (BCR) and Profitability Index, Rate of Returns on Investment, Operating Expense Ratio and Rate of Return on Variable Cost are presented in Table 2. The yam marketers incurred several costs in the course of marketing. These costs were variable costs. The variable costs were expenses on cost of yams, transportation, market space, storage facilities, and labour employed, while the fixed costs include rent on shop/land and depreciation costs of heaps, basket, interest on loan, etc. Yam marketers in the study area spent $\$ 91,233.37$ on variable cost items, representing $90.73 \%$ of the total cost of marketing. Out of this percentage, cost of yams accounted for $64.42 \%$, transportation $4.98 \%$, market space $10.02 \%$, storage facilities $2.51 \%$, labour $4.97 \%$ and the other variable cost item incurred was $3.82 \%$. In all, an average of $\mathrm{N} 100,550.04$ were expenses the marketers incurred. Further result of the analysis in Table 2 generated positive gross margin and net income values of $\$ 75,808.30$ and $\$ 66,491.63$, to prove yam marketing enterprise profitable in the study area (Table 2).

Table 2: Cost and Return Structure Analysis of Yam Marketing.

\begin{tabular}{|c|c|c|}
\hline Variables & Amount $(\mathrm{N})$ & $\%$ of Total cost \\
\hline Total Revenue (TR) & $167,041.67$ & \\
\hline \multicolumn{3}{|c|}{ Variable Cost: } \\
\hline Cost of purchased (yam) & $64,774.31$ & 64.42 \\
\hline Cost of transportation & $5,008.33$ & 4.98 \\
\hline Cost of market space & $10,078.83$ & 10.02 \\
\hline Cost of storage facilities & $2,526.67$ & 2.51 \\
\hline Cost of labour employed & $5,000.00$ & 4.97 \\
\hline Other expenses incurred & $3,845.23$ & 3.82 \\
\hline Total Variable Cost (TVC) & $91,233.37$ & 90.73 \\
\hline \multicolumn{3}{|c|}{ Fixed Cost: } \\
\hline Rent on land/shop & $8,104.17$ & 8.06 \\
\hline Other fixed input & $1,212.50$ & 1.21 \\
\hline Total Fixed Cost (TFC) & $9,316.67$ & 9.27 \\
\hline $\begin{array}{c}\text { Total Marketing Cost (TC }=\text { TVC }+ \\
\text { TFC) }\end{array}$ & $91,233.37$ & 100 \\
\hline Gross Margin (GM = TR - TVC $)$ & $75,808.30$ & \\
\hline Net Income (NI = TR - TMC) & $66,491.63$ & \\
\hline Benefit-Cost Ratio (BCR= TR/TMC) & 1.66 & \\
\hline $\begin{array}{c}\text { Profitability Index or Return on sale } \\
\text { = NI/TR }\end{array}$ & 0.4 & \\
\hline $\begin{array}{c}\text { Return on Investment ( } \mathrm{ROI}=\mathrm{NI} / \\
\text { TMC) }\end{array}$ & 0.66 & \\
\hline $\begin{array}{c}\mathrm{OR}=\text { Operating Expense Ratio }= \\
\text { TVC } / \mathrm{TR}\end{array}$ & 0.55 & \\
\hline $\begin{aligned} \text { RRVC }= & \text { Rate of Return on Variable } \\
& \text { Cost }=(\mathrm{TR} / \mathrm{TVC})\end{aligned}$ & 1.83 & \\
\hline
\end{tabular}

Source: Data Analysis, 2018

Benefit Cost Ratio (BCR) was greater than one. This ratio is one of the concepts of discount method of project evaluation. As a rule of thumb, any business with benefit cost ratio greater than one, equal to one or less than one indicates profit, break-even or loss respectively Olagunju et al. [20]. Since the ratio (BCR $=1.66)$. It implies that yam marketing in the study area is profitable. The Profitability index, return on investment, Operating ratio and Return on variable cost were computed as $0.40,0.66,0.55$ and 1.83 respectively. The PI, RRI, RRVC and OR were all favorable. Return on investment was 0.66 , implying that the marketers' returned $¥ 0.66$ 
for every $\$ 1.00$ invested in the business. This implies that yam marketing in Yewa Division of Ogun State is a profitable business.

\section{Market Margin and Marketing Efficiency of Yam}

Data in Table 3 presents the marketing margin and the marketing efficiency of yam marketing in Yewa Division of Ogun State. The marketing margin was estimated at \$554.10. The marketing efficiency (ME) was estimated at 1.51. The ME estimates was above 1 indicating that the market is highly efficient. Marketing efficiency ranges from zero (0) to infinity. Scarborough et al. [21], noted that if marketing efficiency is less than 1 , it indicates inefficient market whereas if the marketing efficiency is greater than 1 there is excess profit. A market that is efficient does not only bring sellers and buyers together, it enables entrepreneurs to take advantage of opportunities, to innovate and improve in response to demand and price changes (Table 3).

Table 3: SMarketing Margin, and Marketing Efficiency Estimates of Yam.

\begin{tabular}{|c|c|}
\hline Parameter & Value \\
\hline Revenue & $167,041.67$ \\
\hline Cost & $100,550.04$ \\
\hline
\end{tabular}

\begin{tabular}{|c|c|}
\hline Revenue - Cost & $66,491.63$ \\
\hline Total Number of respondents & 120 \\
\hline Marketing Margin $M_{m}$ & 554.1 \\
\hline Marketing Cost = Cost & $100,550.04$ \\
\hline $\begin{array}{c}\text { Marketing Margins } \begin{array}{c}M_{m} \text { x 120 } \\
\text { Cost }\end{array} \\
\text { Mevenue - }\end{array}$ & $66,491.63$ \\
\hline Marketing Efficiency (ME) & 1.51 \\
\hline
\end{tabular}

Source: Data analysis, 2018.

\section{Problems Militating against Yam Marketing in the Study Area}

The results of Figure 1 showed that the respondents considered bad roads (45\%) and poor storage (45\%) as a major constraint and it ranked first among the identified constraints. This was because yam is heavy and fragile, so transporting it can be difficult on a bad road. It is often transported manually using head pans or baskets. Credit sales and Poor and instable price of yam (40.0\%) was also considered a problem. Other problems include, lack of capital, high purchase price, poor sales, too many traders, too many market levies, high cost of transportation and risk of accident or robbery (Figure 2).

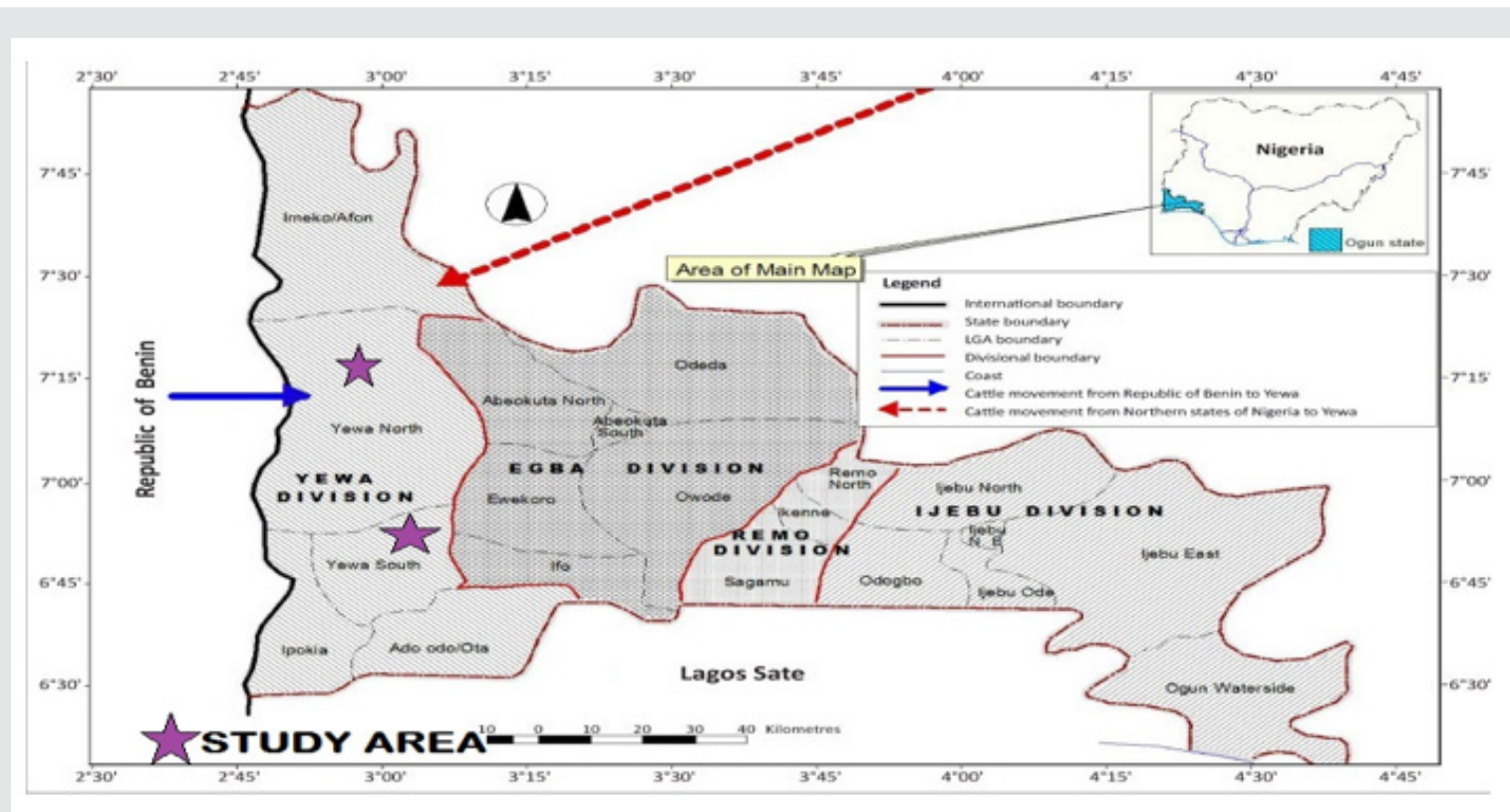

Figure 2: Map of Ogun State showing the study area.

Source: Lamidi and Ogunkunle, (2015)

\section{Conclusion}

The conclusions of the study are that the yam marketers were mainly females who are still in their prime, married and considerably illiterate. Cost of buying yam constituted the main cost of operation. In terms of profitability, yam marketing was highly profitable in the study area with returns that could comfortably offset the cost of capital. The yam market was very efficient with good marketing margin. The problems militating against yam marketing were numerous but the main constraints facing them include bad roads, poor storage, credit sales and Poor and instable price of yam.

\section{References}

1. Egbuna EN (2008) A review of the activities of the national strategic grains reserve: Issue arising, CBN bullion, p. 42-45.

2. Oluwafemi RA (2010) The impact of Agricultural credit on livestock production and owners livelihood. The case of livestock farmers in ovia 
North East LGA of Edo State, Nigeria. International Journal of Business and common Market study 6(2): 34-35.

3. Nigeria Export Promotion Council (NEPC) (2009) Percentage contribution of agriculture to Nigeria GDP.

4. Central Bank of Nigeria (CBN) (2012) Annual Report and statement of Account Report and statement of Account for the Year ended $31^{\text {st }}$ December 2007. CBN publication. Nigeria, p. 12.

5. Okoedo-Okojie D U, GF Okwuokenye (2016) Characteristics and Potentials of Retail Marketing of Yam in Delta State, Nigeria: Implications for the Extension Services. British Journal of Applied Science \& Technology 14(2): 1-8.

6. Toluwase SOW, AB Sekumade (2017) Resource Use Efficiency of Yam Production in Ekiti State, Nigeria. Advances in Social Sciences Research Journal 4(2): 20-34.

7. Adeniji OB, Adebayo CO, Ajayi OP (2012) Analysis of marketing margin of yam in selected rural areas of Niger State, Nigeria. Basic Research Journal of Agricultural Science and Review 1(3): 58-62.

8. Food and Agricultural Organization (FAO) (2002) Food and Agricultural Organization Yearbook, p. 56.

9. Bamire AS, Amujoyebe BJ (2005) Economic Analysis of Land Improvement Techniques in Small holder Yam-Based production systems in the Agro-Ecological zones of south western Nigeria. Journal of Human Ecology 18(1): 1-12

10. IITA (2005) Plant density of yam mini sett. International Institute of tropical Agriculture, pp. 114-118.

11. Okwuokenye GF, Onemolease EA (2011) Influence of socio-economic characteristics of yam sellers on marketing margins among yam wholesalers in Delta State, Nigeria. Journal of Agriculture and Social Research (JASR) 2(1): 81-90.
12. Okoedo-Okojie D U, GF Okwuokenye (2016) Characteristics and Potentials of Retail Marketing of Yam in Delta State, Nigeria: Implications for the Extension Services. British Journal of Applied Science \& Technology 14(2): 1-8.

13. Kotler P (2001) Marketing Management. The millennium edition, Published by Asoke K Ghosh, New Delhi, India. pp. 533-534.

14. Okwuokenye GF, Onemolease EA (2006) Demographic characteristics related to wholesale marketing of yam in Delta State, Nigeria. Journal of Global Approaches to Extension Practice (GAEP) 2(1): 9-15.

15. Robert A, Fred N, John Eudes A, Kwasi O, Simon C, et al. (2012) Estimation of Margins and Efficiency in the Ghanaian Yam Marketing Chain. Asian Journal Agriculture and Rural Development 2(2): 226-234.

16. Lamidi AA, Ogunkunle T (2015) Occurrences of Resources Conflicts Among the Fulani's Herdsmen and Arable Farmers In Yewa Area, Ogun State, Nigeria. Research journali's Journal of Agriculture 2 (1): 1-11.

17. Olusegun Olatunji (2016)

18. Tuffour M, Dokurugu MT (2015) Margins and Efficiency Analysis of Watermelon marketing in Rural Northern Ghana. IOSR Journal of Business and Management 17(2): 58-63.

19. Oladapo MO, Osundare OT, Osundare FO, Oyebamiji K (2015) Effects of infrastructure on yam tuber Marketing in four selected local government areas of Ekiti State, Nigeria. Academia Journal of Biotechnology 3(6): 097-103.

20. Olagunji FI, Adesiyan, IO, Ezekiel, AA (2007) Economic viability of cat fish production in Oyo-State, Nigeria. Journal of Human Ecology 21(2): 121-124.

21. Scarborough V, J Kydd (1992) Economics analysis of agricultural markets. A manual Chatham UK 5.

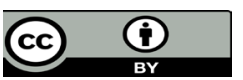

This work is licensed under Creative Commons Attribution 4.0 License

To Submit Your Article Click Here: Submit Article

DOI: 10.32474/CIACR.2019.07.000255

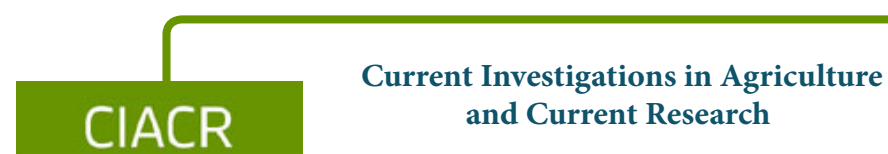

Assets of Publishing with us

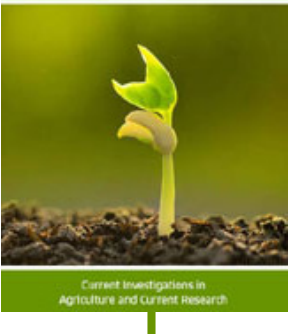

- Global archiving of articles

- Immediate, unrestricted online access

- Rigorous Peer Review Process

- Authors Retain Copyrights

- Unique DOI for all articles 